\title{
Presence of a cryptic Onchocerca species in black flies of northern California, USA
}

\author{
Matthew Kulpa', Kimberly J. Nelson², Alana M. Morales ${ }^{3}$, Bonnie M. Ryan ${ }^{4}$, Michelle L. Koschik, \\ Jamesina J. Scott ${ }^{4}$ and Guilherme G. Verocai ${ }^{*}$
}

\begin{abstract}
Background: Black flies (Diptera: Simuliidae) serve as arthropod vectors for various species of Onchocerca (Nematoda: Onchocercidae) that may be associated with disease in humans, domestic animals, and wildlife. The emergence of zoonotic Onchocerca lupi in North America and reports of cervid-associated zoonotic onchocerciasis by Onchocerca jakutensis highlight the need for increased entomological surveillance. In addition, there is mounting evidence that Onchocerca diversity in North America is far greater than previously thought, currently regarded as Onchocerca cervipedis species complex. This study reports new geographic records and black fly vector associations of an uncharacterized Onchocerca species.

Methods: To better understand the biodiversity and geographic distribution of Onchocerca, 485 female black flies (2015: 150, 2016: 335) were collected using $\mathrm{CO}_{2}$-baited traps from February to October 2015-2016 in Lake County, northern California, USA. Individual flies were morphologically identified and pooled ( $\leq 10$ individuals) by species, collection date, and trap location. Black fly pools were processed for DNA extraction, and subsequent PCR and sequencing targeting of the NADH dehydrogenase subunit 5 gene of filarioids.
\end{abstract}

Results: Among the pools of black flies, there were 158 individuals of Simulium tescorum (2015: 57, 2016: 101), 302 individuals of Simulium vittatum (sensu lato [s.l.]) (2015: 82, 2016: 220), 16 individuals of Simulium clarum "black" phenotype (2015: 5, 2016: 11), and 13 individuals of S. clarum "orange" phenotype (2015: 6, 2016: 7). PCR analysis revealed the percentage of filarioid-positive pools were $7.50 \%(n=3)$ for S. tescorum, 3.75\% $(n=3)$ for S. vittatum (s.l., likely S. tribulatum), $7.69 \%$ ( $n=1)$ for S. clarum "black" phenotype, and no positives for S. clarum "orange" phenotype. Genetic distance and phylogenetic analyses suggest that the northern California Onchocerca isolates belong to the same species reported in black flies from southern California (average pairwise comparison: $0.32 \%$ ), and seem closely related to Onchocerca isolates of white-tailed deer from upstate New York (average pairwise comparison: 2.31\%).

Conclusion: A cryptic Onchocerca species was found in Lake County, California, and may be a part of a larger, continentally distributed species complex rather than a single described species of North America. In addition, there are at least three putative vectors of black flies (S. clarum, S. tescorum, S. vittatum) associated with this cryptic Onchocerca species. A comprehensive reassessment of North American Onchocerca biodiversity, host, and geographic range is necessary.

\footnotetext{
*Correspondence: gverocai@cvm.tamu.edu

${ }^{1}$ Department of Veterinary Pathobiology, College of Veterinary Medicine

and Biomedical Sciences, Texas A\&M University, College Station, TX 77843,

USA

Full list of author information is available at the end of the article
} original author(s) and the source, provide a link to the Creative Commons licence, and indicate if changes were made. The images or other third party material in this article are included in the article's Creative Commons licence, unless indicated otherwise in a credit line to the material. If material is not included in the article's Creative Commons licence and your intended use is not permitted by statutory regulation or exceeds the permitted use, you will need to obtain permission directly from the copyright holder. To view a copy of this licence, visit http://creativecommons.org/licenses/by/4.0/. The Creative Commons Public Domain Dedication waiver (http://creativeco mmons.org/publicdomain/zero/1.0/) applies to the data made available in this article, unless otherwise stated in a credit line to the data. 
Keywords: Cervidae, Filarial parasites, Filarioidea, Onchocerciasis, Parasite biodiversity, Vector-borne diseases, Xenomonitoring

\section{Background}

Onchocerca Diesing, 1841, a genus of filarial nematodes, is a globally distributed, vector-borne parasite that infects a wide variety of species that includes both animals and humans [1]. Well-known species of Onchocerca include Onchocerca volvulus (Leuckart, 1893), also known as the agent of river blindness in humans, and the zoonotic parasite Onchocerca lupi Rodonaja, 1967, the agent for causing canine ocular onchocerciasis [2]. Onchocerca species are transmitted via blood-sucking dipteran vectors, including black flies (Simuliidae) and biting midges (Ceratopogonidae), to definitive mammalian hosts [1].

Despite the zoonotic potential and possible deleterious impacts to host health of most Onchocerca species, little is known about the clinical and ecological significance of the ungulate parasite Onchocerca cervipedis Wehr and Dikmans, 1935, or what is commonly known as the "foot worm." Described nearly a century ago [3], O. cervipedis has an extensive distribution range from areas of Central America to Canada, and infects a variety of cervids including the white-tailed deer Odocoileus virginianus (Zimmermann, 1780); mule deer Odocoileus hemionus (Rafinesque, 1817); moose Alces americanus Clinton, 1822; elk or wapiti Cervus canadensis Erxleben, 1777; and caribou Rangifer tarandus (Linnaeus, 1758); and the antilocaprid pronghorn Antilocapra americana (Ord, 1815) [4-16]. Onchocerca cervipedis has always been assumed to be the only Onchocerca species to infect these North American ungulates; however, there is mounting evidence that suggests otherwise. Recent studies have shown that Onchocerca isolates from the skin of white-tailed deer from New York [17] were genetically distinct from isolates of moose from northern Canada [15]. In addition, cryptic Onchocerca DNA was discovered from black fly vectors of southern California, and blood analysis supports the notion of a possible Cervidae host [18]. Therefore, all previous reports on Onchocerca across the Americas, including ungulate host and vector associations, require a comprehensive re-evaluation $[15,17$, $18]$.

In order to shed further light on the cryptic diversity of species within Onchocerca from North America, we molecularly screened putative black fly vectors trapped in Lake County, NC, USA, for filarial nematode DNA. We discuss these results in the current context of known cryptic biodiversity and historical biogeography of Onchocerca in North America.

\section{Methods \\ Black fly collection}

Lake County, California, was the designated area targeted for black fly collection. Lake County is located in one of the broad valleys of northern California $\left(122^{\circ} 50^{\prime} \mathrm{W}\right.$, $39^{\circ} 00^{\prime} \mathrm{N}$ ) and contains the largest freshwater lake entirely in California, Clear Lake [19]. Through coordination with the Lake County Vector Control District, female black flies were caught by $\mathrm{CDC}$-style miniature $\mathrm{CO}_{2}$-baited mosquito traps (John W. Hock Company, Gainesville, FL, USA). Dry ice kept in a cooler served as source of $\mathrm{CO}_{2}$, and traps were set overnight at various locations around the shores of Clear Lake, weekly or biweekly, between April 2015 and October 2016 (Fig. 1). Once collected, the black flies were morphologically identified to species/ species-complex level according to taxonomic keys [20]. Adult S. clarum black flies were recognized by a distinct three-striped scutal pattern, but were differentiated by stripe color type. All samples were stored at $-80{ }^{\circ} \mathrm{C}$ until further analysis.

\section{Molecular screening and sequencing}

Individual flies were morphologically identified and pooled ( $\leq 10$ individuals) by species, collection date, and trap location (Table 1; Fig. 1). DNA extraction of pools of black flies was performed manually using the Qiagen DNeasy ${ }^{\odot}$ Blood and Tissue Kit (Qiagen, Valencia, CA, USA). Briefly, black flies were macerated with sterile plastic pestles in an Eppendorf tube, and homogenized with ATL buffer and proteinase K. Samples were then incubated in a dry heat block for $45 \mathrm{~min}$ at $56{ }^{\circ} \mathrm{C}$, and then centrifuged for $5 \mathrm{~min}$ at $8000 \times g$. The remaining protocol steps followed the manufacturer's instructions. DNA lysates were kept refrigerated at $-20{ }^{\circ} \mathrm{C}$ until further processing.

Polymerase chain reactions (PCR) targeting the mitochondrial NADH dehydrogenase subunit $5(n d 5)$ gene of filarioid nematodes, using the primers ND5-Ov5A-F (5'-TTGGTTGCCTAAGGCTATGG-3') and ND5OvC$\mathrm{R}$ (5'-CCCCTAGTAAACAACAAACCACA-3') [21]. Cycling conditions consisted of $95^{\circ} \mathrm{C}$ for $2 \mathrm{~min}$, followed by 35 cycles of $95^{\circ} \mathrm{C}$ for $30 \mathrm{~s}, 50^{\circ} \mathrm{C}$ for $45 \mathrm{~s}$, and $72{ }^{\circ} \mathrm{C}$ for $30 \mathrm{~s}$, and a final extension at $72{ }^{\circ} \mathrm{C}$ for $5 \mathrm{~min}$, following previously published protocols [18]. 


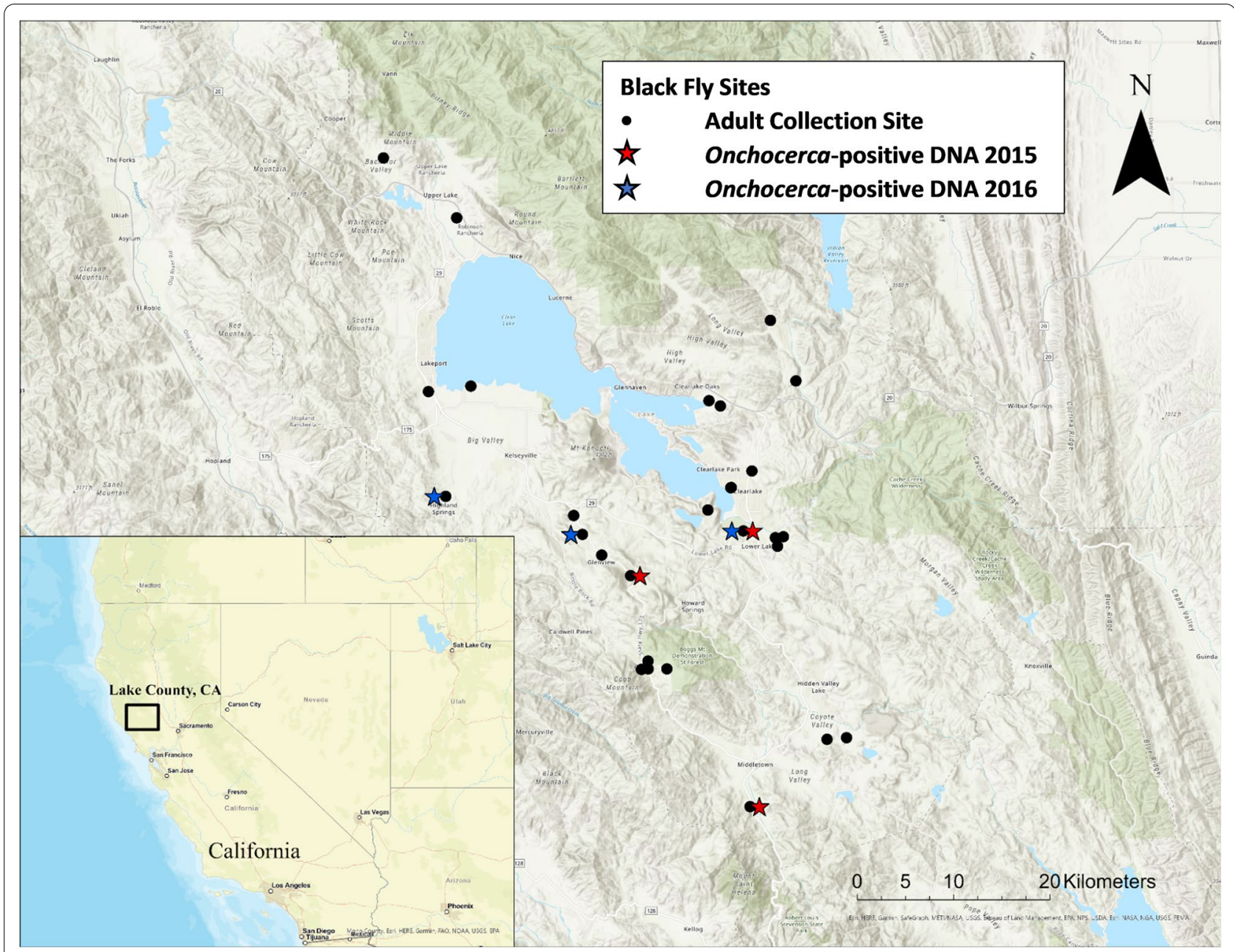

Fig. 1 Locations of adult black fly collection sites in Lake County, California. Each collection site is marked with a black dot. Sites denoted with a right-staggered red star indicate an Onchocerca-positive PCR test in $2015(n=4)$, and sites denoted with a left-staggered blue star indicate an Onchocerca-positive PCR test in $2016(n=3)$

Potential PCR products were subjected to agarose gel to determine if amplicon was present. An E.Z.N.A. Cycle Pure Kit (Omega Bio-tek, Norcross, GA, USA) was used to purify DNA using the manufacturer's protocol. Products were then directly sequenced with the same primers using the BigDye Terminator Cycle Sequencing Kit.

\section{Phylogenetic analysis}

Sequences were aligned and edited using MEGA X software [22]. Phylogenetic trees of the partial $n d 5$ gene (427 bp) were constructed by utilizing the maximum likelihood method and Tamura-Nei model with gamma distribution in 2000 bootstrap replicates. All sequences at the $n d 5$ gene for Onchocerca species available through GenBank were included. Dirofilaria immitis (Leidy, 1856) and Dirofilaria repens Railliet and Henry, 1911 were used as outgroups within the family Onchocercidae.

\section{Taxonomy of simuliid vectors and mammalian hosts for Onchocerca}

The taxonomy of black flies and artiodactyl mammalian hosts followed the most recent and comprehensive literature $[20,23,24]$.

\section{Results}

A total of 485 black flies were collected from 27 different collection sites in the Lake County area (Fig. 1). Overall, 150 flies were collected in 2015, and 335 flies in 2016, representing three black fly species. Of these, 158 individuals were identified as Simulium tescorum Stone and Boreham, 1965 (2015: 57, 2016: 101), 302 individuals of 
Table 1 Summary of positive black flies according to their year and collection sites

\begin{tabular}{|c|c|c|c|c|c|c|}
\hline & $\begin{array}{l}\text { Number } \\
\text { examined }\end{array}$ & Number of pools & Positive black fly pools & Coordinates & Location & $\begin{array}{l}\text { Percentage } \\
\text { of positive } \\
\text { pools by } \\
\text { species (\%) }\end{array}$ \\
\hline \multicolumn{7}{|l|}{2015} \\
\hline S. clarum "black" & 5 & 3 & (1) SCB-15-039 & $38^{\circ} 53^{\prime} 21.9^{\prime \prime} \mathrm{N}, 122^{\circ} 43^{\prime} 53.6^{\prime \prime} \mathrm{W}$ & Kelseyville & 33.3 \\
\hline S. clarum "orange" & 6 & 6 & None & - & - & 0.0 \\
\hline S.tescorum & 57 & 17 & (1) ST-15-010 & $38^{\circ} 43^{\prime} 16.7^{\prime \prime} \mathrm{N}, 122^{\circ} 37^{\prime} 12.8^{\prime \prime} \mathrm{W}$ & Middletown & 5.9 \\
\hline \multirow[t]{2}{*}{ S. vittatum } & 82 & 31 & (1) SV-15-020A & $38^{\circ} 55^{\prime} 3.8^{\prime \prime} \mathrm{N}, 122^{\circ} 35^{\prime} 20.9^{\prime \prime} \mathrm{W}$ & Lower Lake & 6.5 \\
\hline & & & (2) SV-15-043 & $38^{\circ} 55^{\prime} 3.8^{\prime \prime} \mathrm{N}, 122^{\circ} 35^{\prime} 20.9^{\prime \prime} \mathrm{W}$ & Lower Lake & \\
\hline Total & 150 & 57 & 4 & & & 7.0 \\
\hline \multicolumn{7}{|l|}{2016} \\
\hline S. clarum "black" & 11 & 10 & None & - & - & - \\
\hline S. clarum "orange" & 7 & 7 & None & - & - & - \\
\hline \multirow[t]{2}{*}{ S. tescorum } & 101 & 23 & (1) ST-16-011 & $38^{\circ} 56^{\prime} 49.5^{\prime \prime} \mathrm{N}, 122^{\circ} 54^{\prime} 14.3^{\prime \prime} \mathrm{W}$ & Lakeport & 8.7 \\
\hline & & & (2) ST-16-014 & $38^{\circ} 55^{\prime} 10.2^{\prime \prime} \mathrm{N}, 122^{\circ} 46^{\prime} 35.5^{\prime \prime} \mathrm{W}$ & Kelseyville & \\
\hline S. vittatum & 220 & 49 & (1) SV-16-030A & $38^{\circ} 55^{\prime} 19.1^{\prime \prime} \mathrm{N}, 122^{\circ} 37^{\prime} 35.0^{\prime \prime} \mathrm{W}$ & Lower Lake & 2.0 \\
\hline Total & 335 & 89 & 3 & & & 3.4 \\
\hline \multicolumn{7}{|l|}{ 2015-2016 } \\
\hline S. clarum "black" & 16 & 13 & 1 & - & - & 7.7 \\
\hline S. clarum "orange" & 13 & 13 & 0 & - & - & 0.0 \\
\hline S. tescorum & 158 & 40 & 3 & - & - & 7.5 \\
\hline S. vittatum & 302 & 80 & 3 & - & - & 3.8 \\
\hline Overall total & 485 & 146 & 7 & & & 4.8 \\
\hline
\end{tabular}

Black flies were collected in the 2015-2016 field season using $\mathrm{CO}_{2}$-baited traps in the Lake County, California area. Four species of black flies were caught: S. clarum (black); S. clarum (orange) S. tescorum; and S. vittatum. However, S. clarum (orange) had no positive individuals. Each row denotes the number of black flies examined, the number of pools $(n=\leq 10)$, the positive black fly pools, coordinates and cities of where the positive was located, and the percentage of positive pools by species

Simulium vittatum Lugger, 1897 (sensu lato [s.l.], likely $S$. tribulatum) (2015: 82, 2016: 220), 16 individuals of Simulium clarum (Dyar and Shannon, 1927) "black" phenotype (2015: 5, 2016: 11), and 13 individuals of Simulium clarum "orange" phenotype (2015: 6, 2016: 7).

Regarding the samples collected in 2015, a total of $2 / 31$ S. vittatum pools (6.5\%), $1 / 17$ S. tescorum pools (5.9\%), and $1 / 3$ S. clarum "black" phenotype pools (33.3\%) were positive for filarioid DNA and subsequently sequenced for Onchocerca DNA (Table 1). In 2016, a total of $1 / 49$ S. vittatum pools $(2.0 \%)$ and $2 / 23$ S. tescorum pools (8.7\%), were positive for filarioid DNA and subsequently sequenced (Table 1$)$. All positive $S$. vittatum $(n=3)$ pools came from Lower Lake, while each of the $S$. tescorum positive pools $(n=3)$ came from three different locations: Middletown, Lakeport, and Kelseyville. The single positive S. clarum "black" phenotype $(n=1)$ was also found in Kelseyville (Table 1).

All seven generated $n d 5$ sequences were deposited in the GenBank (Accession numbers: MZ420192-98). Phylogenetic analysis showed strong support that the Lake County Onchocerca isolates in northern California are conspecific with the isolates from Los Angeles in southern California (94\% bootstrap support), and likely belong to an uncharacterized species (Fig. 2). In addition, the upstate New York Onchocerca isolates appear to be closely related to both Californian isolates $(92 \%$ bootstrap support) (Fig. 2). Other Onchocerca isolates or species that have been reported from North American wildlife, namely $O$. cervipedis sensu Verocai et al. [15] of moose from Canada, and O. lupi reported from companion animals, coyotes, and humans in North America [25-27], were not included within this clade.

Pairwise distance data (Table 2) also show strong support for each of the three geographic isolates being closely related to one another. Of the three, both Californian isolates are more similar to each other, with a pairwise distance averaging $0.32 \%(0.00-2.54 \%)$. The New York Onchocerca isolate had an average pairwise distance of $2.31 \%(2.12-3.27 \%)$ when compared to the Lake County isolates, and 2.34\% (2.12-3.27\%) when compared to the Los Angeles isolates. On the other hand, when Lake County isolates were compared to O. cervipedis sensu Verocai et al. [15] isolates, there was a pairwise distance of $10.04 \%$ (9.64-10.64\%). These genetic distances are similar to interspecific Onchocerca species 


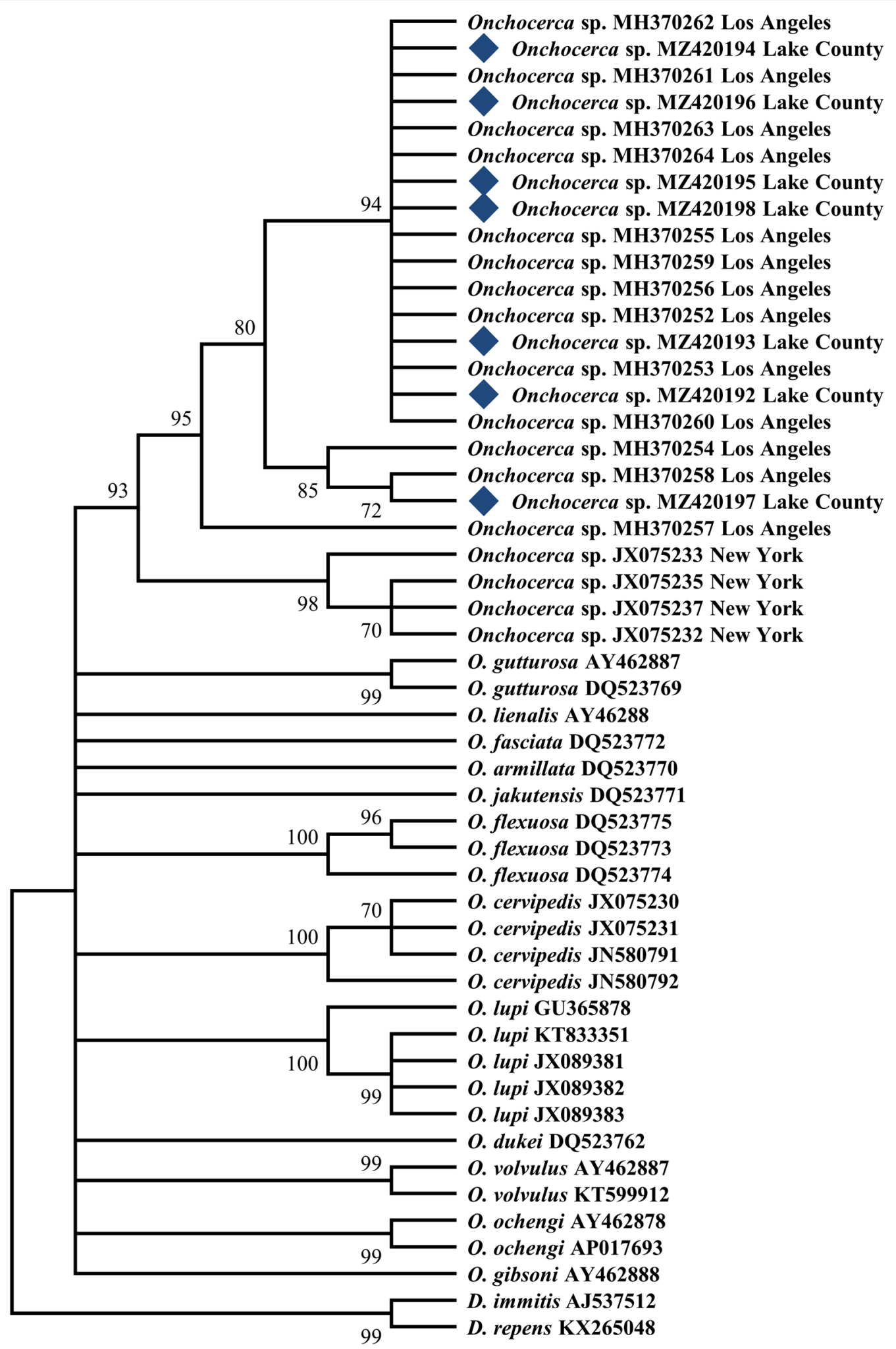

Fig. 2 Maximum likelihood tree depicting phylogenetic relationship of the nd5 gene between species of known Onchocerca and the cryptic Onchocerca DNA found across geographic isolates of Onchocerca in California and New York, USA, created with MEGA X. Branches with less than 50\% bootstrap were collapsed and bootstrap support shown besides branches indicate 2000 replicates. All cryptic DNA samples obtained from black flies from Lake County, California, are denoted with a black diamond and have been accessioned in GenBank (MZ420192; MZ420193; MZ420194; MZ420195; MZ420196; MZ420197; MZ420198) 
Table 2 Average pairwise comparisons, with ranges in parentheses, of nd5 gene with different Onchocerca isolates or species

\begin{tabular}{|c|c|c|c|c|c|c|}
\hline Onchocerca isolate & Lake County, CA & Los Angeles, CA & Upstate New York & Onchocercasp. & Onchocerca lupi & Reference \\
\hline Lake County, CA & $0.24 \%(0.00-0.95 \%)$ & & & & & Present study \\
\hline Los Angeles, CA & $0.32 \%(0.00-2.26 \%)$ & $0.48 \%(0.00-2.54 \%)$ & & & & {$[18]$} \\
\hline Upstate New York & $2.31 \%(2.12-3.27 \%)$ & $2.34 \%$ (2.12-3.27\%) & $0.24 \%(0.00-0.48 \%)$ & & & [17] \\
\hline Onchocerca sp. & $\begin{array}{l}10.04 \%(9.64- \\
10.64 \%)\end{array}$ & $9.93 \%$ (7.65-11.11\%) & $9.47 \%$ (8.61-9.77\%) & $0.12 \%(0.00-0.24 \%)$ & & [15] \\
\hline Onchocerca lupi* & $\begin{array}{l}11.75 \%(11.24- \\
11.86 \%)\end{array}$ & $\begin{array}{l}11.82 \%(11.24- \\
12.21 \%)\end{array}$ & $\begin{array}{l}10.30 \%(9.18- \\
10.70 \%)\end{array}$ & $\begin{array}{l}10.99 \%(10.53- \\
11.13 \%)\end{array}$ & $0.61 \%(0.00-1.51 \%)$ & Various sources \\
\hline
\end{tabular}

Onchocerca isolates are broken down by region (Lake County, CA; Los Angeles, CA; and Ithaca, NY) or by the species it is from (O. Iupi; Onchocerca sp.). Onchocerca lupi was chosen because it is a North American Onchocerca species that is not considered part of the hypothesized Onchocerca cervipedis species complex

comparisons like O. lupi, 11.75\% average (11.24-11.86\%), rather than intraspecific comparisons (Table 2; Fig. 3). The majority of pairwise comparisons fall outside the range of $\sim 2.00-5.00 \%$ (Table 2; Fig. 3), which is comparable to other studies comparing interspecific versus intraspecific based on pairwise distances at the partial cox-1 gene of the genus Onchocerca [2]. However, when the New York isolate is compared to either Californian isolate, all pairwise comparisons fall within the range of $2.00-5.00 \%$. While evidence clearly indicates that all Californian isolates are conspecifics (Table 2; Fig. 3), the phylogenetic relationships among the New York and Californian isolates remain ambiguous. Table 3 shows the average and range percent identity among Lake County Onchocerca isolates and other isolates also shown in Table 2 using BLAST analysis.

\section{Discussion}

Our study identified cryptic Onchocerca DNA in three different Simulium species in southern California, USA. We discovered that Onchocerca isolates found in black flies in Lake County, northern California, belong to the same cryptic Onchocerca species previously found in black flies in Los Angeles County, southern California [18]. Corroborating the findings from southern California, Onchocerca DNA was detected in two black fly species: S. vittatum (s.l.) and S. tescorum [18] (Table 1). In addition, a third species of black fly was shown to carry the same cryptic Onchocerca DNA: S. clarum belonging to the "black" phenotype (Table 1).

Phylogenetic analyses of the $n d 5$ gene demonstrate that the cryptic Onchocerca found in southern and northern California black flies (present study; [18]) and the equally cryptic Onchocerca isolate found in New York, northeastern USA [17] represent one individual clade with little genetic divergence (Fig. 2). However, a definitive conclusion on whether the Californian isolates are conspecific with the New York isolates cannot yet be determined (Table 2; Fig. 3). Further studies targeting a multilocus approach could help shed light on the exact phylogenetic relationships and taxonomic status of these geographically distant isolates. This notion is best exemplified by comparing the $n d 5$ gene to the $c o x-1$ gene, which appears to exhibit greater diversity within the cryptic Onchocerca isolates [18]. In addition, at this stage, it is not possible to conclude that the cryptic species present in northern California belongs to the originally described $O$. cervipedis. In the original description of the species by Wehr and Dikmans [3], the authors used specimens from two different locations and at least two different hosts, including O. virginianus and O. hemionus from Montana, USA, and O. hemionus from British Columbia, Canada. To further elucidate this taxonomic conundrum, isolates from these hosts and locations should be collected, morphologically re-evaluated, molecularly characterized, and subsequently compared to these many isolates within the Onchocerca complex.

\section{Molecular screening and putative vectors of cryptic Onchocerca isolates}

The finding of cryptic Onchocerca DNA through molecular screening of arthropod vectors (i.e., xenomonitoring) provides a straightforward approach to understanding more about parasite biodiversity, geographic distribution, and putative vector associations. Moreover, the utilization of xenomonitoring of North American parasites allows for concurrent monitoring of other similar Onchocerca species, such as the zoonotic O. lupi, that are of current public health concern [28]. However, despite these advantages, implication of a given arthropod species in the transmission of Onchocerca should be cautiously interpreted until further demonstrated by recovering infective third-stage larvae or parasite DNA from the head of the vector, and/or experimentally. Comparable to Verocai et al. [18], our results showed that the positivity rate for Onchocerca DNA was low in the black fly populations. This is similar to other filarial nematode studies that revealed low positive prevalence rates of $O$. 


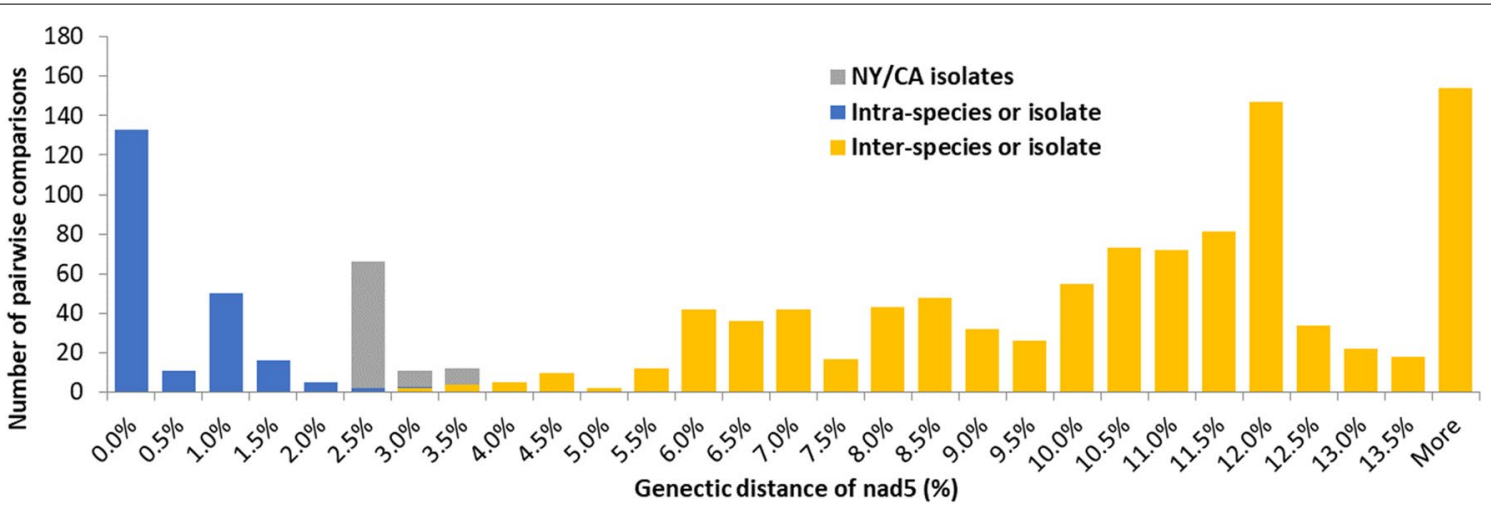

Fig. 3 The number of base substitutions per site are calculated and the evolutionary divergence is estimated between sequences. Each bar represents the total amount of pairwise comparisons of the nd5 gene, or nucleotide sequence divergence, from 50 different Onchocerca species or isolates. Evolutionary analysis was done using MEGA X and a Tamura-Nei model with gamma distribution. Blue bars indicate supposed intra-isolate comparisons and orange bars indicate supposed inter-isolate comparisons of all Onchocerca species or discovered isolates. Lake County, CA and Los Angeles, CA isolate comparisons have been treated as intra-specific species. Gray bars indicate NY-CA isolate comparisons

Table 3 Average percent identity of Lake County isolates compared to other known Onchocerca isolates, using NCBI BLAST analysis, at the nd5 gene level

\begin{tabular}{|c|c|c|c|c|c|c|c|}
\hline \multirow[b]{2}{*}{$\begin{array}{l}\text { Accession } \\
\text { numbers }\end{array}$} & \multicolumn{7}{|l|}{ Lake County, CA } \\
\hline & MZ420192 & MZ420193 & MZ420194 & MZ420195 & MZ420198 & MZ420196 & MZ420197 \\
\hline $\begin{array}{l}\text { Los Angeles, CA } \\
\text { [18] }\end{array}$ & $\begin{array}{l}99.76 \%(98.57- \\
100 \%)\end{array}$ & $\begin{array}{l}99.76 \%(98.57- \\
100 \%)\end{array}$ & $\begin{array}{l}99.76 \%(98.57- \\
100 \%)\end{array}$ & $\begin{array}{l}99.76 \%(98.57- \\
100 \%)\end{array}$ & $\begin{array}{l}99.76 \%(98.57- \\
100 \%)\end{array}$ & $\begin{array}{l}99.76 \%(98.57- \\
100 \%)\end{array}$ & $\begin{array}{l}99.26 \% \\
(97.87-100 \%)\end{array}$ \\
\hline $\begin{array}{l}\text { Upstate New } \\
\text { York [17] }\end{array}$ & $\begin{array}{l}96.42 \%(94.57- \\
100 \%)\end{array}$ & $\begin{array}{l}96.42 \%(94.57- \\
100 \%)\end{array}$ & $\begin{array}{l}96.42 \%(94.57- \\
100 \%)\end{array}$ & $\begin{array}{l}96.42 \%(94.57- \\
100 \%)\end{array}$ & $\begin{array}{l}96.42 \%(94.57- \\
100 \%)\end{array}$ & $\begin{array}{l}96.42 \%(94.57- \\
100 \%)\end{array}$ & $\begin{array}{l}95.70 \% \\
(94.03-97.37 \%)\end{array}$ \\
\hline $\begin{array}{l}\text { Onchocerca sp. } \\
\text { [15] }\end{array}$ & $\begin{array}{l}92.09 \%(91.94- \\
92.04 \%)\end{array}$ & $\begin{array}{l}92.08 \%(91.92- \\
92.38 \%)\end{array}$ & $\begin{array}{l}92.09 \%(91.94- \\
92.04 \%)\end{array}$ & $\begin{array}{l}92.09 \% \text { 91.94- } \\
92.04 \%)\end{array}$ & $\begin{array}{l}92.08 \%(91.92- \\
92.38 \%)\end{array}$ & $\begin{array}{l}92.12 \%(91.86- \\
92.43 \%)\end{array}$ & $\begin{array}{l}91.95 \% \\
(91.63-92.36 \%)\end{array}$ \\
\hline Onchocerca lupi & $\begin{array}{l}91.81 \%(91.74- \\
92.00 \%)\end{array}$ & $\begin{array}{l}91.79 \%(91.72- \\
92.00 \%)\end{array}$ & $\begin{array}{l}91.81 \%(91.74- \\
92.00 \%)\end{array}$ & $\begin{array}{l}91.81 \%(91.94- \\
92.00 \%)\end{array}$ & $\begin{array}{l}91.79 \%(91.72- \\
92.00 \%)\end{array}$ & $\begin{array}{l}91.82 \% \text { (91.76- } \\
92.00 \%)\end{array}$ & $\begin{array}{l}92.05 \% \\
(91.99-92.24 \%)\end{array}$ \\
\hline
\end{tabular}

Onchocerca isolates are broken down by region (Lake County, CA; Los Angeles, CA; and Ithaca, NY) or by the species it is from (O. lupi; Onchocerca sp.). Onchocerca lupi was chosen because it is a North American Onchocerca species that is not considered part of the hypothesized Onchocerca cervipedis species complex

lupi in southern California [28], O. volvulus in Africa [29, 30], and Wuchereria bancrofti (Cobbold, 1877) in American Samoa and Guinea [31-33].

Our study also provided evidence for an additional species of black fly as a probable vector of this Onchocerca species. Although three black fly species have been implicated as possible intermediate hosts for this Onchocerca, it should be noted that the $\mathrm{CO}_{2}$ trapping method utilized may impact the abundance and species composition of black flies caught [34]. According to the literature, $S$. clarum has been reported to feed on a variety of mammals (horses, cattle, rabbits, and humans) and birds [35, 36]. The finding of DNA of an Onchocerca species possibly associated with a cervid host(s) suggests that these mammals may serve as a blood source for this dipteran, similar to that of S. tescorum and S. vittatum, as suggested by Verocai et al. [18, 20]. However, S. clarum is restricted to the California Central Valley region near the present study site of Lake County [20]. Similarly, $S$. tescorum has been reported with a limited range, spanning only California and Arizona [20, 23]. This means that even if these two vectors are competent hosts for this Onchocerca species, they would only contribute to the transmission within their more restricted distribution. In contrast, species within the $S$. vittatum complex, which includes $S$. tribulatum, have a widespread distribution across North America, including both California and New York [23].

\section{Definitive hosts of cryptic Onchocerca isolates}

While relevant literature suggests that this Onchocerca isolate is associated with cervid hosts [17, 18], there is a lack of experimental data to definitively confirm this hypothesis. However, the recent discoveries of at least two or more genetic Onchocerca isolates in North 
America hypothesized to be associated with at least three of the cervid hosts (i.e., mule deer, white-tailed deer, and moose) raise many questions regarding Onchocerca-host assemblages. Of these three cervid hosts, only the mule deer's range encompasses southern California, including Los Angeles County [37-39]. Thus, it was reasonably hypothesized that the mule deer could be the putative host to the Onchocerca isolate from southern California if the parasite is truly associated with cervid hosts [18]. Lake County also includes the range of the mule deer [37]; however, unlike southern California, Lake County is also home to the Californian tule elk, or Cervus elaphus nannodes Merriam, 1905 [40]. This elk subspecies was hunted to near extinction in the late 1800s, and now has a thriving population in California. According to most recent data, about 6000 tule elk populate California, including many herds that live near the Lake County region of northern California where black flies were sampled for this current study [40-42]. While there was no blood meal analysis completed, it is possible that these cervids could be a blood meal source for black flies and consequently be a potential host to the hypothesized O. cervipedis species complex [8]. Ideally, adult worms or microfilariae should be sampled from necropsied elk hosts and molecularly analyzed to confirm its definitive host status.

Species within $O$. cervipedis complex have been reported in a variety of locations across North America in the six ungulate hosts: pronghorn from Idaho [9]; moose from Alaska, Alberta, British Columbia, and the Northwest Territories [12, 14-16, 43]; elk from Montana [8]; mule deer from Arizona, California, Montana, Utah, Wyoming, and British Columbia [3-5, 7, 8, 10, 18, 44-52]; white-tailed deer from Arizona, Missouri, Montana, New York, Oregon, Pennsylvania, and British Columbia, and also from Costa Rica [3, 5, 6, 8, 13, 17, 46, 50, 53-57]; and caribou from Alaska and British Columbia [11, 15]. Additional records from Odocoileus from Colorado, Idaho, and Montana were reported as "deer," without species designation [58-62]. Therefore, it can be inferred that sample collection should begin in these reported locations and include all six ungulate hosts when obtaining biological samples. Recovery of nematodes from necropsy, with subsequent morphological and DNA identification, will confirm parasitic infection of a definitive host and aid in interpreting the distribution of cryptic Onchocerca isolates.

\section{Evolutionary history and ecological considerations of cryptic Onchocerca isolates}

Currently, it is hypothesized that the two, and possibly more, known Onchocerca species (i.e., O. cervipedis sensu Verocai et al. [15] and the clade comprising the
Californian and New York isolates $[17,18]$ ) are the result of independent expansion events from Palearctic ungulates hosts colonizing from across the Bering Land Bridge into the Nearctic [63-65]. It is currently unknown if the finding of at least two Onchocerca species is the result of a small, incomplete sampling of larger species diversity or the true representation of diversity in North America. Nevertheless, there is substantial evidence from eastern Asia for prior underestimation of Onchocerca species diversity and richness. For instance, Onchocerca suzukii Yagi, Bain and Shoho, 1994, Onchocerca eberhardi Uni et al., 2007, and Onchocerca takaokai Uni, Fukuda and Bain, 2015, have been recently described from wild ungulates of Japan [66-68]. Furthermore, Onchocerca borneensis Uni, Mat Udin and Takaoka, 2020 [69], was described in bearded pigs of Borneo with additional molecular evidence suggesting that two closely related parasites, Onchocerca dewittei Bain, Ramachandran, Petter and Mak, 1977, and Onchocerca japonica Uni, Bain and Takaoka, 2001, which were considered subspecies of the former were, in fact, separate species [69]. Indeed, it is feasible that the North American Onchocerca species complex, about which much is still unknown, could comprise undescribed Onchocerca diversity, similar to the pattern that we have witnessed in Asian suids and ungulates. Moreover, host-parasite biogeography appears to play a critical role in Onchocerca diversification. As noted by Uni et al. [69], O. borneensis and O. dewittei infect Sus barbatus Müller and Sus scrofa vittatus Boie in the Indomalayan region, but O. japonica and O. dewittei infect different subspecies of the same host species in the Palearctic and Indomalayan regions. Thus, when reevaluating Onchocerca in the North American landscape, collecting specimens from sympatric and allopatric host ranges may yield more complete information about parasitic diversity.

\section{Conclusion}

A cryptic Onchocerca species was found in Lake County, California, which is likely conspecific to isolates previously characterized from southern California. Putative vectors of this cryptic parasite include $S$. tescorum and $S$. vittatum. In addition, a previously unrecognized black fly vector, S. clarum, was discovered to be a potential vector. In order to understand the true biodiversity of the genus Onchocerca in North America, a complete continental re-evaluation of definitive hosts, vector associations, and geographic distribution is necessary through the integration of classical and molecular methods.

\footnotetext{
Acknowledgements

We would like to thank the Lake County Vector Control District and all whose support made this study possible.
} 


\section{Authors' contributions}

MK and GGV drafted the manuscript. GGV acquired funding. BMR, MLK, AAM and JJS performed blackfly collections and KJN performed identification. GGV performed the molecular genetic study. All authors read and approved the final manuscript.

\section{Funding}

Not applicable.

\section{Availability of data and materials}

The data supporting the conclusions of this article are included within the article. The sequences have been submitted to the GenBank database under the accession numbers MZ420192-MZ420198 (nd5).

\section{Declarations}

\section{Ethics approval and consent to participate}

Not applicable.

\section{Consent for publication}

Not applicable.

\section{Competing interests}

The authors declare that they have no competing interests.

\section{Author details}

${ }^{1}$ Department of Veterinary Pathobiology, College of Veterinary Medicine and Biomedical Sciences, Texas A\&M University, College Station, TX 77843, USA. ${ }^{2}$ San Gabriel Valley Mosquito and Vector Control District, West Covina, CA, USA. ${ }^{3}$ Department of Infectious Diseases, College of Veterinary Medicine, University of Georgia, 501 D.W. Brooks Drive, Athens, GA 30602, USA. ${ }^{4}$ Lake County Vector Control District, 410 Esplanade St., Lakeport, CA 95453, USA

Received: 28 June 2021 Accepted: 1 September 2021

Published online: 15 September 2021

\section{References}

1. Anderson RC. Nematode parasites of vertebrates: their development and transmission. Wallingford: CABI Publishing; 2000.

2. Lefoulon E, Giannelli A, Makepeace BL, Mutafchiev Y, Townson S, Uni S, et al. Whence river blindness? The domestication of mammals and hostparasite co-evolution in the nematode genus Onchocerca. Int J Parasitol. 2017:47:457-70

3. Wehr EE, Dikmans G. New Nematodes (Filariidae) from North American Ruminants. Zool Anz. 1935;202-8.

4. Annereaux R. A new record of a deer parasite for California. Am J Vet Res. 1941:2:199-201.

5. Caballero Y. Morfologia y posicion sistematica de Onchocerca cervipedis. Rev Bras Biol. 1954:4:557-62

6. Carreno RA, Durden LA, Brooks DR, Abrams A, Hoberg EP. Parelaphostrongylus tenuis (Nematoda: Protostrongylidae) and other parasites of white-tailed deer (Odocoileus virginianus) in Costa Rica. Comp Parasitol. 2001:68:177-84

7. Cowan IM. Parasites, diseases, injuries, and anomalies of the Columbian black-tailed deer, Odocoileus hemionus columbianus (Richardson), in British Columbia. Can J Res. 1946;24:71-103.

8. De Nio RM, West RM. The foot-worm disease in deer of the northern Rocky Mountain region. J For. 1942;40:540-3.

9. Dikmans G. Onchocerca flexuosa from the subcutaneous tissues of an antelope and subcutaneous abscesses of a deer. J Parasitol. 1933;19:246.

10. Herman CM, Bischoff Al. The foot worm parasite of deer. Calif Fish Game. 1946:32:182-90.

11. Low W. Parasites of woodland caribou in Tweedsmuir Provincial Park, British Columbia. Can Field-Nat. 1976:90:189-91.

12. Ritcey R, Edwards R. Parasites and diseases of the Wells Gray Moose Herd. J Mammal. 1958:39:139-45.

13. Rush W. Onchocerciasis, a new disease in the white-tailed deer of Montana. J Mammal. 1935:16:70-1.
14. Samuel W, Barrett M, Lynch G. Helminths in moose of Alberta. Can J Zool. 1976:54:307-12.

15. Verocai GG, Lejeune M, Beckmen KB, Kashivakura CK, Veitch AM, Popko RA, et al. Defining parasite biodiversity at high latitudes of North America: new host and geographic records for Onchocerca cervipedis (Nematoda: Onchocercidae) in moose and caribou. Parasit Vectors. 2012;5:242.

16. Williams RB, Babero BB. Onchocerca in an Alaskan moose. J Mammal. 1958;39:449-50.

17. McFrederick QS, Haselkorn TS, Verocai GG, Jaenike J. Cryptic Onchocerca species infecting North American cervids, with implications for the evolutionary history of host associations in Onchocerca. Parasitology. 2013;140:1201-10.

18. Verocai GG, Nelson KJ, Callahan RT, Wekesa JW, Hassan HK, Hoberg EP. A cryptic species of Onchocerca (Nematoda: Onchocercidae) in blackflies (Simulium spp.) from southern California, USA. Parasit Vectors. 2018;11:547.

19. Goldman CR, Wetzel RG. A study of the primary productivity of clear lake, Lake County. California Ecol. 1963;44:283-94.

20. Adler P, Currie D, Wood D. The Black Flies (Simuliidae) of North America. Comstock Pub. Associates, Ithaca, NY. 2004.

21. Morales-Hojas R, Cheke RA, Post R. Molecular systematics of five Onchocerca species (Nematoda: Filarioidea) including the human parasite, $O$. volvulus, suggest sympatric speciation. J Helminthol. 2006;80:281-90.

22. Kumar S, Stecher G, Li M, Knyaz C, Tamura K. MEGA X: molecular evolutionary genetics analysis across computing platforms. Mol Biol Evol. 2018;35:1547

23. Adler PH, Crosskey RW: World blackflies (Diptera: Simuliidae): a Comprehensive Revision of the Taxonomic and Geographical Inventory. https:// biomia.sites.clemson.edu/pdfs/blackflyinventory.pdf. (2016). Accessed 15 May 2021.

24. Grubb P. Order artiodactyla. In: Wilson DE, Reeder DM, editors. Mammal species of the world: a taxonomic and geographic reference. Baltimore: The Johns Hopkins University Press; 2005. p. 652-722.

25. Cantey PT, Weeks J, Edwards M, Rao S, Ostovar GA, Dehority W, et al. The emergence of zoonotic Onchocerca lupi infection in the United States-a case-series. Clin Infect Dis. 2016:62:778-83.

26. Roe CC, Yaglom H, Howard A, Urbanz J, Verocai GG, Andrews L, et al. Coyotes as Reservoirs for Onchocerca lupi, United States, 2015-2018. Emerg Infect Dis. 2020;26:2989.

27. Verocai GG, Conboy G, Lejeune M, Marron F, Hanna P, MacDonald E, et al. Onchocerca lupi nematodes in dogs exported from the United States into Canada. Emerg Infect Dis. 2016:22:1477.

28. Hassan HK, Bolcen S, Kubofcik J, Nutman TB, Eberhard ML, Middleton K, et al. Isolation of Onchocerca lupi in dogs and black flies, California, USA. Emerg Infect Dis. 2015;21:789-96.

29. Katholi CR, Toé L, Merriweather A, Unnasch TR. Determining the prevalence of Onchocerca volvulus infection in vector populations by polymerase chain reaction screening of pools of black flies. J Infect Dis. 1995:172:1414-7.

30. Yamèogo L, Toe L, Hougard J-M, Boatin BA, Unnasch TR. Pool screen polymerase chain reaction for estimating the prevalence of Onchocerca volvulus infection in Simulium damnosum sensu lato: results of a field trial in an area subject to successful vector control. Am J Trop Med. 1999:60:124-8.

31. Chadee D, Williams S, Ottesen E. Xenomonitoring of Culex quinquefasciatus mosquitoes as a guide for detecting the presence or absence of lymphatic filariasis: a preliminary protocol for mosquito sampling. Ann Trop Med Parasitol. 2002;96:S47-53.

32. Kouassi BL, de Souza DK, Goepogui A, Narh CA, King SA, Mamadou BS, et al. Assessing the presence of Wuchereria bancrofti in vector and human populations from urban communities in Conakry, Guinea. Parasit Vectors. 2015;8:1-9

33. Schmaedick MA, Koppel AL, Pilotte N, Torres M, Williams SA, Dobson SL, et al. Molecular xenomonitoring using mosquitoes to map lymphatic filariasis after mass drug administration in American Samoa. PLoS Negl Trop Dis. 2014;8:e3087.

34. Anderson J, Yee W. Trapping black flies (Diptera: Simuliidae) in Northern California. I: Species composition and seasonal abundance on horses, host models, and in insect flight traps. J Vector Ecol. 1995;20:7-25.

35. Anderson JR, Voskuil G. A reduction in milk production caused by the feeding of blackflies (Diptera: Simuliidae) on dairy cattle in California, 
with notes on the feeding activity on other animals. Mosq News. 1963;23:126-31.

36. Reeves W, Asman S, Hardy J, Millby M, Reisen W. Epidemiology and Control of Mosquito-borne Arboviruses in California, 1943-1987. Sacramento, CA: California Mosquito and Vector Control Association. 1990;128-44

37. Pérez-Solano LA, Gallina-Tessaro S, Sánchez-Rojas G. Individual variation in mule deer (Odocoileus hemionus) habitat and home range in the Chihuahuan Desert. Mexico J Mammal. 2016;97:1228-37.

38. Hundertmark K: Alces alces. The IUCN red list of threatened species 2016. (2016). Accessed Downloaded on 09 June 2021.

39. Gallina S, Lopez Arevalo H. Odocoileus virginianus. The IUCN red list of threatened species. (2016). Accessed Downloaded on 09 June 2021.

40. Batter TJ, Bush JP, Sacks BN. Assessing genetic diversity and connectivity in a tule elk (Cervus canadensis nannodes) metapopulation in Northern California. Conserv Genet. 2021;1-13. https://doi.org/10.1007/ s10592-021-01371-0.

41. Ciriacy-Wantrup S, Phillips WE. Conservation of the California Tule Elk: a socioeconomic study of a survival problem. Biol Conserv. 1970;3:23-32.

42. Watt LA. The continuously managed wild: tule elk at point Reyes National Seashore. J Int Wildl Law Policy. 2015;18:289-308.

43. Pledger DJ: Black flies (Diptera, Simuliidae) of the Swan Hills, Alberta as possible vectors of Onchocerca cervipedis Wehr and Dikmans, 1935 (Nematoda, Onchocercidae) in moose (Alces alces Linnaeus). MSci Thesis, University of Alberta, Edmonton; 1978.

44. Duckworth CU. Division of Animal Husbandry. 21 Ann Rep Calif Dept Agr: 1941. pp. 352-69.

45. Herman CM. Further observations on deer foot worm infection. Calif Fish Game. 1947;33:54.

46. Hibler CP. Description of the Microfilaria of Wehrdikmansia cervipedis (Wehr and Dikmans, 1935) and Observations on its Location in Arizona Deer. Bull Wildl Dis Assoc. 1965;1:44-8.

47. Jensen LA, Pederson JC, Andersen FL. Prevalence of Elaeophora schneideri and Onchocerca cervipedis in mule deer from central Utah. Great Basin Nat. 1982:42:3.

48. Landram JF, Honess RF. Some internal parasites of the mule deer Odocoileus hemionus hemionus in Wyoming. Wyom Game Fish Comm. 1955:8:13-22.

49. Voge M. A list of nematode parasites from California mammals. Am Midl Nat. 1956;56:423-9.

50. Walker ML, Becklund WW. Checklist of the internal and external parasites of deer, Odocoileus hemionus and O. virginianus, in the United States and Canada. Index-Catalogue Med Vet Zool. 1970;1 Special Publ:45.

51. Weinmann CJ, Anderson JR, Longhurst WM, Connolly G. Filarial worms of Columbian black-tailed deer in California 1. Observations in the vertebrate host. J Wildl Dis. 1973;9:213-20.

52. Yuill TM, Low JB, Fitzgerald PR. The foot worm of northern Utah deer. Wildl Dis. 1961;10.

53. Beaudoin RL, Samuel WM, Strome CP. A comparative study of the parasites in two populations of white-tailed deer. J Wildl Dis. 1970;6:56-63.
54. Latham R. Common diseases and parasites of wild animals. Penn Game News. 1955;26:17-25.

55. Robbins DJ, Clark GG. Filariasis in Missouri white-tailed deer. J Parasitol. 1978;64:567-8.

56. Samuel W. Parasites of Pennsylvania Deer. Penn Game News. 1967;38:25-7.

57. Shaw JN. Some Parasites of Oregon Wildlife. Oreg Agr Exp Sta Tech Bull. 1947;11:1-16

58. Butler WJ. Onchocerca flexuosa (in a deer shot in Broadwater County). Rep Montana Livestock San Bd and State Vet. 1936;15.

59. Dikmans G. A note on the caudal papillae of the male of Wehrdikmansia cervipedis (Wehr and Dikmans, 1935) Caballero, 1945. Proc Helmintholo Soc Wash. 1947;14:34-5.

60. Herman CM. Some worm parasites of deer in California. Calif Fish Game. 1945;31:201-8.

61. Senger CM. Notes on the ecto and endoparasites of the Rattlesnake deer herd. Proc Mont Acad Sci. 1959;18:33.

62. Senger CM. Some parasites of Montana deer. Montana Wild 1963;Autumn:5-13.

63. Hoberg EP, Brooks DR. A macroevolutionary mosaic: episodic host-switching, geographical colonization and diversification in complex host-parasite systems. J Biogeogr. 2008:35:1533-50.

64. Hoberg EP, Brooks DR. Beyond vicariance: integrating taxon pulses, ecological fitting, and oscillation in evolution and historical biogeography. Biogeogr Host-Parasite Interact. 2010;7:7-20.

65. Hoberg EP, Galbreath KE, Cook JA, Kutz SJ, Polley L. Northern host-parasite assemblages: history and biogeography on the borderlands of episodic climate and environmental transition. Adv Parasitol. 2012;79:1-97.

66. Uni S, Bain O, Agatsuma T, Harada M, Torii H, Fukuda M, et al. Onchocerca eberhardi n. sp. (Nematoda: Filarioidea) from sika deer in Japan; relationships between species parasitic in cervids and bovids in the Holarctic region. Parasite. 2007;14:199-211.

67. Uni S, Fukuda M, Agatsuma T, Bain O, Otsuka Y, Nakatani J, et al. Onchocerca takaokai n. sp. (Nematoda: Filarioidea) in Japanese wild boars (Sus scrofa leucomystax): description and molecular identification of intradermal females. Parasitol Int. 2015;64:493-502.

68. Yagi K, Bain O, Shoho C. Onchocerca suzukii n. sp. O. skrjabini $(=0$. tarsicola) from a relict bovid, Capricornis crispus, in Japan. Parasite. 1994;1:349-56.

69. Uni S, Udin ASM, Agatsuma T, Junker K, Saijuntha W, Bunchom N, et al. Description, molecular characteristics and Wolbachia endosymbionts of Onchocerca borneensis Uni, Mat Udin \& Takaoka n. sp.(Nematoda: Filarioidea) from the Bornean bearded pig Sus barbatus Müller (Cetartiodactyla: Suidae) of Sarawak, Malaysia. Parasit Vectors. 2020;13:50.

\section{Publisher's Note}

Springer Nature remains neutral with regard to jurisdictional claims in published maps and institutional affiliations.
Ready to submit your research? Choose BMC and benefit from:

- fast, convenient online submission

- thorough peer review by experienced researchers in your field

- rapid publication on acceptance

- support for research data, including large and complex data types

- gold Open Access which fosters wider collaboration and increased citations

- maximum visibility for your research: over $100 \mathrm{M}$ website views per year

At BMC, research is always in progress.

Learn more biomedcentral.com/submissions 